\title{
The role of income inequality in crisis theories and in the subprime crisis
}

\author{
Thomas Goda
}

May 2013

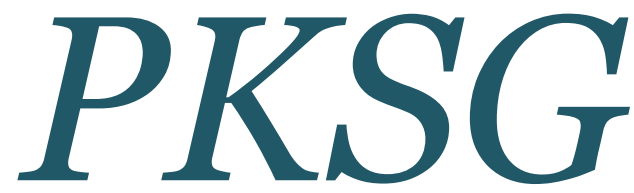

\section{Post Keynesian Economics Study Group}

Working Paper 1305

This paper may be downloaded free of charge from www.postkeynesian.net (C) Thomas Goda 2013.

Users may download and/or print one copy to facilitate their private study or for non-commercial research and may forward the link to others for similar purposes. Users may not engage in further distribution of this material or use it for any profit-making activities or any other form of commercial gain. 


\title{
The role of income inequality in crisis theories and in the subprime crisis
}

\begin{abstract}
An increasing number of economists argue that income inequality was a root cause behind the subprime crisis of 2007. The aim of this paper is to outline and contrast the theoretical underpinnings of Marxian, Post Keynesian and mainstream crisis theories and to compare their viewpoints regarding the role that inequality plays. The main finding of this paper is that despite important theoretical differences, economists from all three strands provide a similar explanation for the link between inequality and the subprime crisis (even though conventional mainstream crisis theories do not regard inequality as destabilizing factor). This suggests that the rise in income inequality indeed played an important role in the build-up of the crisis. To ensure that a wider audience accepts inequality as a prominent causal factor for the crisis it is however necessary that the negative effects of wealth concentration are also taken into account.
\end{abstract}

Keywords: income inequality, crisis theories, subprime crisis

JEL classifications: B0; D3; E25; G01

I would like to thank Photis Lysandrou, John Sedgwick, Chris Stewart, Özlem Onaran, and Humphrey Shaw for their helpful comments.

\section{Thomas Goda}

Universidad EAFIT

School of Economics and Finance

Carrera 49 Número 7 Sur 50

Medellín, Colombia

tgoda@eafit.edu.co 


\section{Introduction}

Research on the impact of changes in distribution on economic processes and social matters has a long standing history in economics and was prominent in the works of Smith, Ricardo, Marx, and Keynes. Although the topic became somewhat out of fashion in the last quarter of the $20^{\text {th }}$ century (Atkinson, 1997) economists, Marxians and post-Keynesians in particular, continued to theoretise the possible negative impacts of income inequality. One of the reasons for this unwaning interest is the finding that a rise in income inequality was a major weakness of the economic system prior to and during the Great Depression (see Eccles; 1951; Galbraith, 1975). Another reason is that intra-country income inequality was increasing in most countries after 1980 and that income inequality between global citizens was very high prior to the outbreak of the recent global financial crisis (Goda, 2013). An increasing number of studies, from different economic strands, therefore suggest that a decrease of the wage share coupled with an increase of top incomes was a root cause of the subprime crisis of 2007.

The aim of this paper is verify the possibility that income inequality played an important role in the build-up of the crisis by undertaking a thorough review of the existing literature. Given that different economic strands have diverging explanations as to why economic crises take place, it is necessary to begin first with a broad explanation of different theoretical concepts and viewpoints and the role of inequality in these theories before the role of income inequality in the subprime crisis can be understood fully. To my knowledge this approach represents a novelty of this paper. Due to space limitations this review will be done for the two economic schools that most extensively discuss the relation between income inequality and crises, Marxism and post-Keynesianism, and for the two dominant economic schools of today's time, neo-classical economics and new-Keynesianism. For simplicity reasons the latter two are discussed under the heading mainstream economics ${ }^{1}$.

The main findings of this paper are: (i) in all Marxian crisis theories class struggle is an important element but only the overproduction/underconsumption theory sees rising inequality as the root cause for crises; (ii) for many post-Keynesians possible aggregate demand problems due to changes in the functional income distribution between workers, capitalists and rentiers are also at the heart of the analysis; but, fundamental uncertainty and Minskian instability are at least as prominent in post-Keynesian crisis theories; (iii) prior to

\footnotetext{
${ }^{1}$ The justification for this approach is that, in contrast to Marxian and post-Keynesian crisis theories, neoclassical and new-Keynesian economics are published in today's top-ranked economic journals.
} 
the crisis mainstream theories and models did not regard inequality as destabilizing factor; (iv) despite important theoretical differences, economists from all three strands provide a similar explanation for the link between inequality and the subprime crisis.

The layout of this paper is as follows. Section two reviews the role of inequality in Marxian crisis theories. Section three reviews the role of inequality in post-Keynesian crisis theories. Section four reviews the role of inequality in mainstream crisis theories. Section five discusses the link between income inequality and the collapse of the US subprime mortgage market. Section six concludes.

\section{Marxian crisis theories and the role of income inequality}

\subsection{Marxian theories of crisis: an overview}

The common denominator on which Marxists agree is that the capitalist system is inherently unstable because its internal contradictions will periodically result in a fall of the rate of profit to a point at which capital accumulation is negatively affected and a crisis breaks out ${ }^{2}$. The reason that lower profits lead to a crisis and not only to a slowdown of economic growth is the existence of the 'contract-credit system'. This implies that payment obligations exist which cannot be served anymore if the rate of profit falls too strongly (Crotty, 1985). However, Marx's followers disagree about the main reason for the fall in profit rates. This is understandable as "Marx appears to associate crises with the tendency for the rate of profit to fall, with tendencies to overproduction, underconsumption, disproportionality and over-accumulation with respect to labour" (Clarke, 1994, p.7). Furthermore, Marx is not consistent in giving primacy to one of these causes. He states for example in Grundrisse and in the three volumes of Capital, that the law of the tendency for the rate of profits to fall is fundamental to understand the limits of capitalism and that capital is the main barrier for capitalist production; but, at the same time he writes that prior to a crisis wages are always rising - implying that this is the main reason for the fall in profits. At the same time, Marx repeatedly stresses the point that ultimately crises are caused by poverty and restricted consumption. This ambiguity is not surprising given that Marx never formulised a full-fledged crisis theory and that most of his remarks on the vulnerability of the capitalist system to crises were not laid down in finished works but stem from notebook

\footnotetext{
${ }^{2}$ According to Marx there are several countertendencies which prevent crises, e.g. increasing productivity, credit, increasing labour resistance if wages fall etc, however, these tendencies work only temporarily and cannot prevent that a crisis finally occurs.
} 
entries which only got published after his death (e.g. Grundrisse and Capital Volume II and III) $)^{3}$.

Nevertheless, Marxians have developed three main approaches to explain capitalist crises on the basis of the different fragments of crisis theories in Marx's texts. Some argue that crises arise due to problems at the first stage of the accumulation process, where money is converted into constant capital (machines, raw material etc.) and variable capital (labour), because either real wages increase and/or raw material becomes more expensive due to scarcity; both leading to a profit squeeze due to higher costs. A second group explains crisis with the inherent contradiction in the production process which leads to the law of the tendency for the rate of profit to fall - due to an increasing constant to variable capital ratio. A third group argues that problems to sell the produced commodities at a price above production costs, i.e. the realisation of surplus value due to overproduction and/or underconsumption, is the main cause for the falling profit rates (Sweezy, 1942; Shaikh, 1978; Kenway, 1980; Clarke, 1994; Bell and Cleaver, 2002; Evans, 2004; Harvey, 2010a). The conclusion that one could draw from this ambiguity is that it is not possible to give primacy to one of these three theories but that the capitalist system faces many potential threats that can lead to a crisis (e.g. very low wages can be as devastating for the functioning of the capitalist system as can be very high wages on the ground that both can undermine capitalist profits to such a degree that accumulation stops).

However, since Marx's death intensive debates about the 'real' Marxian crisis theory have taken place and the vogue between different approaches has changed in the last 120 years, depending on the strength of the argumentation, but also depending on the political and economic environment. Initially the followers of Marx were broadly divided into overproduction and/or underconsumption (e.g. Engels, 1975; Kautsky, 1901-1902; Luxemburg, 1913) and disproportionality (e.g. Hilferding, 1910) crisis theorists ${ }^{4}$. Although the two theories are not incompatible, tensions between these camps grew over time with each of them claiming that their approach was the authentic way to understand and explain the underlying cause of economic crises. The debate between these two camps came to an end in 1942 when Paul Sweezy solved fundamental flaws in the existing overproduction/underconsumption theories. Since then disproportional theories became of

\footnotetext{
${ }^{3}$ Therefore it is surprising that many Marxists argue that 'their' theoretical approach is the only authentic Marxian one and that other approaches are either not valid or only of minor importance. Nowadays these claims come mainly from Marxists that state that the tendency for the profit rate to fall is the real root cause for all crises (see e.g. Yaffe, 1972, Shaikh, 1978, Brenner, 2009; Freeman, 2010, Kliman, 2012).

${ }^{4}$ See Sweezy (1942) and Clarke (1994) for an excellent overview about the historical debates among Marxists.
} 
secondary importance in explaining capitalist crises ${ }^{5}$. In the 1960 s increasing numbers of Marxist scholars began to argue that the inherent tendency of the rate of profit to fall is the real root cause of all capitalist crises, although Sweezy and Baran developed the overproduction/underconsumptionist argument further in 1966. The importance of this 'law' had been stressed earlier (e.g. Dobb, 1939) but it only became the mainstream argument among Marxist circles during the crisis years in the 1970's (see e.g. Mattick, 1971; Shaikh, 1978). At the same time also the profit squeeze theory became highly popular among some Marxists (see e.g. Glynn and Sutcliffe, 1972; Rowthorn, 1980). The main reason for this shift in thought was that the 1970s crises could not be solved by Keynesian demand management and thus could not be explained in terms of underconsumption but instead seemed to be based on an erosion of company profits either due to an increase in the accumulation of constant capital or due to an increase in wage shares (Clarke, 1994).

\subsection{Inequality and its role in Marxian explanations for crises}

The issue of distribution is inherent in all Marxian crisis theory as all theories are based on the notion of class struggle between capitalists and workers which in one way or another ultimately leads to falling profits for the former which is followed by a crisis ${ }^{6}$. According to Marx, the source of capitalists' profit is surplus value which is created by the exploitation of variable capital: labour output can be divided into output paid for with wages and output which is appropriated by capitalists; the bigger the latter the higher the surplus value created by labour. The degree of exploitation thus depends on real wages, labour time, and the productivity of workers. If, ceteris paribus, working time or output increase or real wages decrease surplus value automatically increases. For capitalists, however, it is not the surplus value but the profitability of their investment in constant and variable capital that is the main measure of success. To decrease unit costs capitalist thus increase their constant capital stock to increase the productivity of labour (i.e. to use less labour per unit produced).

Accordingly, supporters of the 'tendency for the profit rate to fall' theory argue that the main reason for all crises is that the rate of profit falls if the amount of constant capital

\footnotetext{
5 Although most Marxists still see disproportionality as very important to explain and understand capitalist crises, it is nowadays rather seen as a trigger of a crisis which is caused by more fundamental contradictions within the capitalist system.

${ }^{6}$ The outcome of a crisis is that profits rise again because production capacity will be reduced (which leads to the destruction of some constant capital and a reduction in production) and rising unemployment leads to a reduction in real wages.
} 
increases more than the level of exploitation (i.e. the capital to surplus value ratio increases). To be more precise, "neither growing worker resistance nor rising real wages are the intrinsic causes of mechanization, though they may well speed up this tendency" (Shaikh, 1978, p. 233), instead the pressure to expand production and increase productivity (as a cause of intensified competition) is the real underlying reason for the increasing investment in constant capital (ibid, 1978; Bell and Cleaver, 2002; Evans, 2004). In other words, the followers of this theory see inequality as an outcome of the capitalist process but not as the root cause of crises. According to the second Marxist theory, the profit squeeze theory, a decrease in income inequality can be the root cause of a crisis. The argument is that an expanding scale of operation leads to more employment (i.e. to a reduction of the so called reserve army), which strengthens the bargaining position of the workers. If the subsequent rise in real wages is higher than the simultaneous increase in the exploitation of workers, capitalists' profits will fall, leading to less accumulation and hence a crisis ${ }^{7}$.

The only Marxian theory which focuses directly on rising income inequality as a possible root cause for capitalist crises is the overproduction/underconsumption theory. This theory has different strands, however, the main logic behind it is that the produced surplus value needs to be realised (i.e. the output needs to be sold) to make profits and capitalists have the tendency to produce more than can be sold. Capitalists are producing to become richer (and not to fulfil people's needs and wants) and they are forced to increase their output due to competition (self-preservation). The increased accumulation leads to a higher overall output. At the same time each capitalist tries to reduce wage costs (employment and salaries) to a minimum. While this strategy makes sense for every individual capitalist, ultimately capitalists' success is bounded by consumption demand: "Production mediates consumption; it creates the latter's material; without it, consumption would lack an object. But consumption also mediates production, in that it alone creates for the products the subject for whom they are products. The product only obtains its 'last finish' in consumption. ... Without

\footnotetext{
${ }^{7}$ Since its increasing popularity in the 1970s the profit squeeze theory has been widely criticised to be nonMarxian (see Shaikh, 1978, Clarke, 1994 and Evans, 2004 for an overview of the criticism). However, this criticism is somehow hard to explain as already at earlier points in time Marxians acknowledged that Marx stressed the important role that rising wages can play. Sweezy (1942, pp.149-154), for example, stresses that the profit squeeze theory is well documented in Marx's writings throughout all three volumes of Capital, e.g. "if one were to attempt ... saying that the working class receive too small a portion of their own product, and the evil would be remedied by giving them a larger share of it, or raising their wages, we should reply that crises are precisely always preceded by a period in which wages rise generally ... it seems, then, that capitalist production comprises certain conditions [that] permit the working class to enjoy that relative prosperity only momentarily, and at that always as a harbinger of a coming crisis (Capital II, p. 475-6, italics added)".
} 
production, no consumption; but also, without consumption, no production" (Marx, 1993, p.91).

Consequently, a reduction in employment and real wages can lead to a crisis if it substantially reduces the spending capacity of the working class (capitalists also consume but their demand for luxury goods has natural limits) ${ }^{8}$. Without adequate consumption demand, capitalists have no motive to increase their investment spending. Their extra output cannot be sold for a profit since they need to lower their prices to be able to sell all of their output. An increase in inequality can thus lead to stagnation or to a crisis if the result is massive overproduction (Sweezy, 1942; Baran and Sweezy, 1966; Bellamy Foster and Magdoff, 2009; Harvey, 2010a) $)^{9}$.

\section{Post-Keynesian crisis theories and the role of income inequality}

\subsection{Post-Keynesian theories of crisis: an overview}

Post-Keynesian economics is mainly inspired by the theories of John M. Keynes but "post-Keynesians [also] derive inspiration from a variety of [other] sources ... such as Marx, ... Kalecki, Kaldor, Leontief, Sraffa, Veblen, Galbraith, Andrews, Georgescu-Roegen, Hicks or Tobin, or from other disciplines (sociology, history, political science, psychology and anthropology)" (Lavoie, 2006, p.18). Although their influences are so diverse, postKeynesian economists are often grouped into two main strands: the fundamentalistKeynesians (which work in the lines of Davidson, Harrod, Minsky, Kregel, Robinson, and Weintraub) and the non-fundamentalist Keynesians (which mainly work in the lines of Eichner, Kaldor, Kalecki, Pasinetti, Robinson, and Sraffa). This demarcation is not clear cut though - as can be seen for example by the inclusion of Robinson in both camps - and the exact definition of post-Keynesianism has led to extensive debates among post-Keynesians (see e.g. Crotty, 1980; Hamouda and Harcourt, 1988; Arestis, 1996; Davidson, 2003-2004; Kerr, 2005; King, 2005; Lavoie, 2005).

\footnotetext{
${ }^{8}$ Another reason why the surplus value might not be realised could be that the additional output has no usevalue for consumers because markets become saturated. Consequently, capitalists are always forced to invent new product lines, to open up new sectors, and to undertake huge advertising campaigns (Bell and Cleaver, 2002; Harvey, 2010a).

${ }^{9}$ Prior to Marx, Malthus (1820) and Sismondi (1827) developed an underconsumption theory which however differs from Marx's theory in that in Malthus' and Simondi's eyes the purpose of production is consumption and not the creation of surplus value.
} 
The main difference between fundamentalist and non-fundamentalist Keynesians nowadays is that the former especially stress the importance of the non-neutrality of money ${ }^{10}$, fundamental (non-ergodic) uncertainty ${ }^{11}$, and non-gross substitution ${ }^{12}$, while the latter mainly concentrate their research on the effects of changes in the income distribution between workers, capitalists and rentiers ${ }^{13}$. Common denominators in post-Keynesian analyses are their emphasis on realism, uncertainty and social and institutional factors, their rejection of Say's law, their insistence on the fallacy of composition (i.e. the belief that micro foundations are often not suitable to theorise the macroeconomy), and their doubt about the beneficial self-equilibration of markets. Probably most importantly, all post-Keynesians see effective aggregate demand as the driving force of the economic system and they believe that investment determines savings, and not the other way around as neoclassical economists claim (Arestis, 1996; Lavoie, 2006). Consequently, post-Keynesian literature discusses three main factors that can destabilise the economic system: (i) an increase in uncertainty, (ii) the endogeneity of money and financial fragility, and (iii) changes in the distribution of income between workers, capitalists, and/or rentiers.

According to post-Keynesians, economic output depends on aggregate private consumption demand, aggregate investment, government expenditures and net exports (Stockhammer, 2008). Investment is seen to be driven by expected profitability which is driven by (expectations about) consumption demand, labour and capital costs, prices of financial assets, and interest rates. Hence, "it is the interaction between the sum of the individual firms' sales expectations (aggregate demand) and their production costs (aggregate supply) that together determine the development in output and employment" (Jespersen, 2009, p.199). Rising uncertainty with regard to sales expectations and production costs can

${ }^{10}$ According to Davidson (1984) "[m]oney matters in the long and short run; i.e., money is not neutral - it affects real decision making" (p.562) and thus "has an impact on the real sector" (p.569).

${ }^{11}$ Past information does not always permit stochastic predictions of the future according to Keynes (1937): "By 'uncertain' knowledge, let me explain, I do not mean merely to distinguish what is known for certain from what is only probable. The game of roulette is not subject, in this sense, to uncertainty... Or, again, the expectation of life is only slightly uncertain. Even the weather is only moderately uncertain. The sense in which I am using the term is that in which the prospect of a European war is uncertain, or the price of copper and the rate of interest twenty years hence, or the obsolescence of a new invention, or the position of private wealthowners in the social system in 1970. About these matters there is no scientific basis on which to form any calculable probability whatsoever. We simply do not know." (pp.213-214).

${ }^{12}$ I.e., "[n]onproducible assets that can be used to store savings are not gross substitutes for producible assets in savers' portfolios" (Davidson, 1984, p.567).

${ }^{13}$ In theory, workers receive their income only out of wages, while capitalists receive their income out of profits and rentiers receive their income through dividends, interest payments, rents, and capital gains. However, in reality many households occupy various contradicting class positions, e.g. capitalists and workers receive also rentier income, and managers are occupying the class position of capitalists (as they are executing power in firms), workers (as they are employed and receive wage income), and rentiers (through their stock options) at the same time (Stockhammer, 2004). 
thus lead to a crisis as it can distort the accumulation process, i.e. it can reduce the 'animal spirits' of entrepreneurs and increase their liquidity preferences, so that they stop investing as they are fearing the risk involved (see e.g. Ferrari-Filho and Camargo Conceicao, 2005; Harvey, 2010b). Next to its influence on investment and consumption, uncertainty also "necessarily gives rise to the possibility of speculation" (Dymski, 2011, p. 331) as it can trigger a misallocation of credit, financial crises via asset bubbles and bursts, overindebtedness, and/or drastic exchange rate fluctuations (due to huge capital inflows or capital flight). The operation of the (international) financial system is hence seen as inherently instable and crisis prone by post-Keynesian economists (Grabel, 1995; Arestis and Glickman, 2002; Onaran, 2006; Nesvetailova, 2007).

In contrast to neoclassical theory, post-Keynesians believe that money is endogenously created by the system: an increase in credit demand by seemingly creditworthy agents leads to an increase in money supply by the financial system (partly through financial innovation). If financial actors, however, feel that the general default risk grows, their liquidity preference increases automatically and hence the supply of credit will be restricted (Minsky 1986, 1992; Wray, 1990; Lavoie, 2006). Accordingly, an economic crisis occurs if many economic units move from secure hedge financing to speculative financing, and from speculative financing to 'super-speculative' Ponzi financing ${ }^{14}$. This will happen endogenously because economic agents have the tendency to increase their level of indebtedness to (unsustainable) high levels "over periods of prolonged prosperity" (Minsky, 1992, p.8), on the grounds that profit expectations become euphoric over time. Lending and borrowing thus shift endogenously from a stable to a more unstable regime, i.e. banks allow more and more firms to become hedge and Ponzi financing units that consequently need to 'roll-over' their debt constantly. When the euphoria ends and debt levels become too high, asset prices fall and uncertainty and liquidity preferences of financial institutions increase, so that economic units cannot easily 'roll-over' their accumulated debt any longer (especially Ponzi financing units). Consequently, many economic units suddenly become bankrupt which in turn triggers a financial crisis and a recession (ibid, 1986, 1992).

\footnotetext{
${ }^{14}$ Hedge financing implies that economic units can repay their debt and the associated interest obligations with their cash-flow. Speculative financing units are those who can pay back their interest obligations with their cashflow but who need to 'roll-over' (part of) their debt obligations, while the cash-flow of Ponzi financing units is neither sufficient to repay their debt nor the interests resulting from this debt. Ponzi units thus either need to increase their debt levels or to sell assets to be able to pay their interest and debt obligations (Minsky, 1986, 1992).
} 
In addition, changes in the wage share, profit share, and rentier income share are crucial for many post-Keynesians in explaining the functioning of the economic system. In their view, an increase in real wages tends to have a positive impact on the economy as it normally leads to higher aggregate consumption demand (as workers have a higher propensity to consume than capitalists and rentiers). This leads to more employment and triggers investment by firms, which in turn raises productivity which makes further wage increases feasible (Palley, 2010a). A decrease of the wage share, on the contrary, is expected to have negative consequences on aggregate consumption demand and hence might lead to a crisis. However, an increase in the wage share can also have a negative impact on the economy: if higher wages negatively affect (expected) profits of capitalists and the (expected) volume of exports ${ }^{15}$ firms will have fewer incentives to invest, this can possibly lead to less employment and lower accumulation rates. Economies thus can be wage-led or profit-led, depending on which of these two forces dominate ${ }^{16}$ (Bhaduri and Marglin, 1990; Lavoie, 2006; Onaran et al., 2011; Hein, 2011).

An increase in the income share of rentiers (i.e. the financialisation of the economy ${ }^{17}$ ) can 'indirectly' influence the stability of the economy negatively, if it leads to a lower wage share, higher inequality of household income, and increasing debt levels of households (see Section 5). Furthermore, financialisation can have 'direct' negative impacts on aggregate investment demand because an important feature of the financialisation process is an increase in shareholder value orientation, i.e. the management of firms (which is aligned by earnings performance related management compensations) pays high dividends to shareholders and buys back shares to ensure high share prices and capital gains for shareholders ${ }^{18}$, instead of retaining profits. Consequently, non-financial companies (i) have fewer funds available to finance physical investment, and (ii) become increasingly leveraged, which makes it increasingly difficult for these firms to obtain external finance. Thus, capital accumulation has the tendency to decline in finance dominated economies (Stockhammer, 2004, 2005-6,

\footnotetext{
${ }^{15}$ Increasing wage costs make domestic firms less competitive on the world market.

${ }^{16}$ Empirically, "in the medium to long run domestic demand in most of the developed capitalist economies tends to be wage-led" (Hein, 2011, p.31). This finding is supported by a recent ILO study, which additionally finds that the "global economy in aggregate is wage-led [which means that there are] limits of strategies of international competitiveness based on wage competition" (Onaran and Galanis, 2012, p.3). In other words, an increase of the wage share in all countries would have a positive impact on global growth.

17 "Financialization means the increasing role of financial motives, financial markets, financial actors and financial institutions in the operation of the domestic and international economies." (Epstein, 2005, p.3).

${ }^{18}$ Keynes (1936) himself was very critical about the role of rentiers in the capitalist system in general. For him rentiers are 'functionless investors' as "there are no intrinsic reasons for the scarcity of capital" (p.376) and he thus advocated a 'euthanasia of the rentier', i.e. the fixing of the interest rate at a very low level to induce investment, consumption, and secure full employment.
} 
2008; van Treeck, 2009a) and a crisis might occur if this decrease in investment spending is not offset by a sufficient increase in household consumption - aggregate consumption spending possibly rises because of increasing rentier income and wealth effects (i.e. debtfinanced consumption) ${ }^{19}$. Moreover, a crisis might emerge because a finance dominated growth regime increases financial fragility due to the rising leverage ratios within the economy ${ }^{20}$ (Palley, 2007; Hein and van Treeck, 2008; van Treeck, 2009b; Onaran et al. 2011; Bhaduri, 2011; Hein, 2012).

While post-Keynesians believe that instability and disequilibrium are inherent in free market economies they also believe that state intervention can stabilise the economic system to some degree. To be more precise, in contrast to Marxists they think that crises can be avoided if the macro-economy is well managed, financial markets are sufficiently regulated, and the 'golden rule' is followed that real wage growth is in line with labour productivity growth, i.e. that the wage share should be roughly constant ${ }^{21}$ (Shaikh, 1978; Clarke, 1994; Davidson, 2003-4; Setterfield, 2010, 2011; Palley, 2010a; Hein and Stockhammer, 2011).

\subsection{Inequality and its role in post-Keynesian explanations for crises}

"Issues of class, power and distribution of income and wealth are at the heart of [postKeynesian] analysis." (Arestis, 1996, p.114), as we have seen above. In terms of income inequality, post-Keynesians distinguish between the functional and personal income distribution. The functional income distribution is a matter of class: it measures how much of the national income goes to workers (wage-share) and how much of the national income goes to capitalists and rentiers (profit-share); whereas the personal income distribution measures in

\footnotetext{
${ }^{19}$ Financialisation is expected to foster rising asset prices (stock market and housing). However, the increasing wealth of households exists only 'virtually', i.e. it cannot be realised by all households at the same time without affecting the asset prices negatively. That is the reason why the wealth effect primarily works via increasing consumer credits - which become available as households have higher collaterals (Bhaduri et al., 2006).

${ }^{20}$ Please note that financialisation theoretically also can lead to a stable finance-led growth regime, which is most likely if the initial decline in investment is not too high and more than offset by increasing rentiers' household consumption and/or wealth effects, the increase in Tobin's q stimulates investment, interest rates are relatively low, and debt levels are kept below a certain threshold (see e.g. Boyer, 2000; Hein and van Treeck, 2008; Hein, 2012).

${ }^{21}$ This 'golden rule' should avoid inflationary pressure (Hein and Stockhammer, 2011) but it is disputed among post-Keynesians if such pressure exists and thus some post-Keynesians advocate a rising wage share (see e.g. Lavoie, 2006; Onaran and Galanis, 2012). Post-Keynesians do not define what the proportion of the wage share should be, i.e. according to the 'golden rule' the economy should be as stable with a constant wage share of let's say $50 \%$ than with a constant wage share of let's say $80 \%$. This is interesting in terms of policy recommendations because if real wages grow in line with labour productivity than the current levels of inequality would be cemented (if everything else stays constant). To decrease the current levels of inequality some post-Keynesians thus advocate an increase of the top marginal income tax, inheritance taxes and wealth taxes in order to redistribute profits from the top to the bottom (see e.g. Onaran, 2011; Hein and Truger, 2012).
} 
how far the national income is equally distributed among individuals/households (please note, that an increase in the profit share does not necessarily lead to an increased income inequality, however, it is expected to do so normally ${ }^{22}$ ).

As outlined in the previous section, post-Keynesians argue that an increase in the functional income distribution tends to have negative impacts on the economy if the economy is wage-led. Similarly, an increase in the inequality of the personal income distribution can have negative consequences for the stability of the economy because poorer segments of the population have a higher marginal propensity to consume than richer segments of the population, i.e. an increase in income inequality is expected to lead to a decrease in aggregate consumption demand (Palley, 2002; Dutt, 2011; Stockhammer, 2012a). Hence, this postKeynesian argumentation is very similar to the Marxian overproduction/underconsumption theory. This is because an increase in income inequality can lead to a crisis as a result of a systemic consumption demand shortage which subsequently leads to lower capital accumulation and unemployment.

The negative consequences of an increase in income inequality might not be immediately visible in a finance dominated economy though, if the poorer segments of the population are able to accumulate debt due to a greater availability of finance and because of rising asset prices (wealth-effect). However, the rising debt which initially ensures stable or growing aggregate consumption demand eventually becomes a burden to low income households as the interest obligations increase and thus higher saving rates are required by poor households. This means that in the long-run income is redistributed from poorer households to richer households and the consumption of poor households consequently will be constrained. Eventually, this will most likely lead to a debt burdened recession (Palley, 1994; Bhaduri et al., 2006; Dutt, 2006, 2011) or, instead, translate into a financial crisis if rising asset prices and financial innovation enable poor households to engage in Ponzi finance to keep their living standards constant ${ }^{23}$ (Hein and van Treeck, 2008; Bhaduri, 2011).

Increasing income inequality might also be counteracted by declining private sector savings (increasing propensities to consume), increased investment expenditure, and/or a

\footnotetext{
${ }^{22}$ A small shop owner is a capitalist by definition, but his/her income might be lower and grow slower than the income of a manager (who by definition is a worker); or, the rentier income of a pensioner might be lower but grow faster than the wage of a blue-collar worker. However, most profits/rents are distributed to the richest segments of the society, e.g. in the US "[t]he top 10 percent of families as a group accounted for about 85 to 90 percent of stock shares, bonds, trusts, business equity, and non-home real estate" in 2007 (Wolff, 2010, p.20).

${ }^{23}$ Please note that high propensities to consume by rich households, very low interest rates, and infinitely rising asset prices theoretically could lead to a stable growth regime.
} 
trade surplus (i.e. external demand). However, ultimately "a mass-production economy needs mass-consumption markets to support it [and] robust mass-consumption markets rest on a healthy distribution of income." (Palley, 2002, p.11). This argumentation is very much in line with Keynes's original thoughts. In his 'General Theory of Employment, Interest, and Money' Keynes (1936, p.372) states that one of "the outstanding faults of the economic society [is] its arbitrary and inequitable distribution of wealth and incomes", as they lead to a low propensity to consume, and "every weakening in the propensity to consume regarded as a permanent habit must weaken the demand for capital as well as the demand for consumption." (p.106).

\section{Mainstream crisis theories and the role of income inequality}

\subsection{Mainstream theories of crisis: an overview}

In contrast to post-Keynesians and Marxists, orthodox mainstream economists "deny that crisis is inherent ... in capitalist production" (Clarke, 1994, p.5). In their view free market operations (i.e. the forces of supply and demand ${ }^{24}$ ) will ensure that the system is selfregulating via an 'invisible hand' and that economies have equilibrium tendencies, i.e. crises are only exceptional deviations from the normal growth path. This general equilibrium theory is in line with the economic thoughts from classical economists like Smith, Mill, and Ricardo $^{25}$ and assumes that full-employment is the norm, that rational economic agents are maximizing utility, and are fully-informed and homogenous in their behaviour, that no fundamental uncertainty exists, that money is neutral, and that (financial) markets work perfectly efficiently. The resulting efficient market theory implies that assets cannot be persistently over- or undervalued as investors would take advantage of price differences, and hence prices will return nearly immediately to their 'fundamental values' via arbitrage (Friedman, 1952; Fama, 1970, 1991; Clarke, 1994; Nesvetailova, 2007).

According to this neo-classical view rationality will ensure that banks only give money to creditworthy borrowers, and that borrowers will only demand credits up to a level to which they are able to repay the loan with their (rightly expected) future income streams. Additionally, it is assumed that a prudent monetary policy (i.e. a tight money supply) will

\footnotetext{
${ }^{24}$ Neo-Classical economists also believe that self-regulation takes place via adjustments in interest rates and exchange rates. They therefore claim that market interest rates and exchange rates need to be fully flexible.

${ }^{25}$ Although Smith "himself took a broader perspective on self-interest than his modern-day disciples [and] used the term 'invisible hand' with some irony” (Stiglitz, 2011, p.591).
} 
ensure low and stable inflation rates. Consequently, crises are not seen as systemic failures of the real or financial sector but they are seen to result "from some policy miscalculation or governmental ineptness, plain corruption or a severe external shock to the economic system" (Nesvetailova, 2007, pp.26-27) ${ }^{26}$. In other words, crises are regarded as market selfcorrections which are necessary to overcome sporadic exogenous disturbance and/or misguided government policies (like too high government debt levels which lead to 'debt intolerance' by investors, as prominently argued by Reinhart and Rogoff, 2010) and ensure the long-term healthiness of the system.

Research on financial crises in emerging economies by mainstream economists has put some doubt on this orthodox notion that markets work perfectly fine when they are left on their own. The new-Keynesian Krugman (1979), in his so called first generation model on financial crises, was one of the first mainstream economists who claimed that fundamental macroeconomic variables can be negatively influenced by imbalances in the balance of payments of countries. This strand of research was developed further in so called second, third, and fourth generation models of financial crises after they became a widespread problem in developing economies in the 1990s (Muñoz, 2011). The third and fourth generation of these models claim that in financially open economies negative effects of massive capital outflows together with the creditworthiness of the balance sheets of the economy are the two key components to explain financial crises. In other words, (i) countries receive external capital and are getting indebted in foreign currency; (ii) at some point investor's perception of the riskiness of the domestic balance sheets changes, which leads to massive capital outflows (e.g. due to expected depreciation or contagion); (iii) this capital flight weakens the currency and exhausts the reserves of a country; (iv) the already weakened local currency collapses; (v) highly leveraged entities within the country are unable to repay

${ }^{26}$ External shocks are also commonly referred to as 'sunspots'. While those 'sunspots' might influence endogenous variables of the system, ultimately the system is always seen to been thrown out of equilibrium due to random exogenous factors: "Intrinsic uncertainty is caused by stochastic fluctuations in the primitives or fundamentals of the economy. An example would be exogenous shocks that affect liquidity preferences. Extrinsic uncertainty by definition has no effect on the fundamentals of the economy. .... An equilibrium with extrinsic uncertainty is called a sunspot equilibrium, because endogenous variables may be influenced by extraneous variables (sunspots) that have no direct impact on fundamentals. A crisis cannot occur in a fundamental equilibrium in the absence of exogenous shocks to fundamentals, such as asset returns or liquidity demands. In a sunspot equilibrium, by contrast, asset prices fluctuate in the absence of aggregate exogenous shocks, and crises appear to occur spontaneously." (Allen and Gale, 2007, p.129). For example, in Diamond and Dybvig (1983) model bank runs are an idiosyncratic phenomenon. The reason for the bank run is the knowledge of lenders that, due to the maturity mismatch between deposits and credits, banks are not able to repay all deposits at the same time if a bank run occurs on a particular bank. Another reason why a crisis occurs might be that "bank's initial portfolio choices ... in combination with small shocks to the demand for liquidity ... cause a collapse in asset prices [and] substantial asset-price volatility and/or default" (Allen and Gale, 2007, p.148). However, in both models the trigger of the crisis is seen to be an exogenous shock. 
their external (short-term) debts; (vi) the financial and real sector turns into crisis (see e.g. Krugman, 1999; Dornbusch, 2001; Tornell et al., 2004). The key trigger for a financial crisis thus is seen to be the change in the expectations of foreign investors.

The assumption about the endogenous stability and efficiency of markets, however, most prominently got challenged by the imperfect and asymmetric information theory from the new-Keynesian Nobel Prize winners Akerlof (1970) and Stiglitz (with Rothschild, 1976). According to their theory not all market participants have the same information and, therefore, markets work not as perfectly as orthodox economists claim. Firstly, there are difficulties to appropriate the returns for the investment necessary to receive 'first-hand' information because this information spreads quickly in the market. Secondly, one party might have better information than other parties (e.g. a borrower is better informed about the riskiness of an investment than the lender). In other words, market incentives exist (i) to minimise the costs in acquiring information, (ii) to conceal information to other market participants (e.g. agency problems), and (iii) to insure against risk (e.g. credit rationing). This means that market disequilibria can arise endogenously (see Stiglitz (2002) and Rosser (2003) for an excellent overview $)^{27}$.

Accordingly, an economic crisis can result from an economic downturn, which "may be initiated by an oil price shock, a monetary shock, or a dramatic change in expectations" (Stiglitz, 1992, p.284), because information imperfections in the equity market lead to the situation that "relatively small fractions of new capital is raised by new equity issues" (p.278). In addition, banks are starting to restrict their lending, whereas during the predownturn period most investment is financed with credits. The consequence is that firms will not only invest less and hire fewer workers - which has negative impacts on aggregate demand - but also many firms will go bankrupt due to their high debt levels. This in turn will lead to further lending restrictions and less equity issues, and a further exacerbation of the crisis. This theory is also directly linked to third and fourth generation models of financial crises because imperfect and asymmetric information is seen to be crucial to understand why “a sudden change in lenders' perceptions concerning 'emerging market risk' [can emerge, which in turn] can lead to huge capital outflows, undermining the viability of the entire financial system" of a country (Stiglitz, 2000, p.1080). So, in a nutshell, financial fragility is

\footnotetext{
${ }^{27}$ Other market imperfections might be caused "when there are 'externalities' (where one party's actions can have large negative or positive effects on others for which he does not pay or reap the benefits ... or where risk markets or other markets are absent (one can't, for instance, buy insurance against many of the most important risks that one faces)." (Stiglitz, 2012, p.34).
} 
not seen to develop endogenously (i.e. to be inherent to the system) but necessarily "...is a situation in which small shocks have a significant impact on the financial system" (Allen and Gale, 2007, p.126). These shocks may be trivial (bankruptcy, refusal of credit, a suicide, etc.) but they are significant enough to change the perceptions of market participants or to bring an important actor of the system into trouble.

Another strand that challenges the position of the endogenous stability of markets, which has gained more and more attention in recent years and can be seen as an outcome of the asymmetric information theory (see Akerlof, 2002), is the so called behavioural finance theory - based on Kahneman and Tversky's (1979) work and most prominently put forward by Shiller (2000), Shleifer (2000) and Akerlof and Shiller (2009). According to this theory psychology factors like greed, loss of self-control, investor's preferences, overconfidence and -optimism, and under- and over-reactions due to herding behaviour explain financial instability. In other words, the theory assumes that 'non-rational' behaviour leads to speculation and to the deviation of market prices from their 'fundamental' value and explains why bubbles and financial crashes exist ${ }^{28}$.

However, the most widely used mainstream models of today, the so called Dynamic Stochastic General Equilibrium (DSGE) models, normally do not consider the findings of behavioural finance (i.e. the models normally rely on the assumption that all individuals are identical, utility-maximising, and rational), and they also treat incomplete and asymmetric information and agency problems as special cases (i.e. they assume that all markets are in equilibrium). In addition, most DSGE models do not incorporate money, the financial sector (e.g. no borrowing and lending takes place) and/or the government sector in a meaningful realistic sense, and they do not take into account that macroeconomic outcomes can be very different from the existing micro-foundations (for a detailed discussion of the limitations of DSGE models see Dullien (2009) and Stiglitz (2011)). Due to these shortcomings, and more importantly because these 'New Consensus' models "have failed [to] predict that the [recent] financial crisis would happen; and ... understated its effects" (ibid, 2011, p.591), the usefulness of DSGE models is questioned by some prominent mainstream economists.

\footnotetext{
${ }^{28}$ This theory is closely related to the mania and panic theory from Kindleberger (see Kindleberger and Aliber, 2005).
} 


\subsection{Inequality and its role in mainstream explanations for crises}

From the previous discussion it becomes clear that income inequality does not play a prominent role in mainstream discussions of crises. Strangely this is also true for behavioural economics which, to my knowledge, does not discuss changes in the behaviour of households based on changes in inequality levels. For orthodox economists equilibrium is determined by the laws of supply and demand, and institutions and power relations are normally not taken into account. This means that inequality is seen as a 'just' outcome of differences in productivity (e.g. through Cobb-Douglas production functions, see Fischer (2011)), which is not expected to have a destabilising effect on the economic system because changes in earnings, debt and savings are seen as optimal in an economic sense, Say's law is assumed to hold (i.e. supply creates its own demand), and full-employment is assumed as norm.

The fact that inequality is not prominent in mainstream research can also be seen from the fact that the vast majority of DSGE models are based on one representative agent (a notable exception is the work from Kumhof and Ranciere (2010), and Kumhof et al. (2012) that will be discussed in Section 5). This means that "there are no distributive issues [and] no scope for exploitation [because] what the worker loses through lower wages, he/she gets back in his/her role as 'owner' through higher profits" (Stiglitz, 2011, p.598). Furthermore, DSGE models normally disregard the possibility of excess indebtedness, as no financial market is included in most models. In other words, according to the vast majority of mainstream theories and models, inequality will have neither a negative impact on aggregate demand nor will it lead to over-indebtedness ${ }^{29}$. Even if capital markets are taken into account mainstream theories of consumption "... see no link between the inequality of (permanent) income and aggregate personal consumption, and hence no need for government action..." (van Treeck and Sturn, 2012, p.1). The reason for this view is that households are expected to be able to smooth fluctuations in income with the help of financial markets and that inequality is seen to be rather influenced by transitory changes (e.g. depending on the age of the individual) and not by permanent changes in lifetime income (Krueger and Perri, 2006). However, since the onset of the subprime crisis a minority of mainstream economists have questioned these assumptions. These are discussed in detail in the next section.

\footnotetext{
29 A notable exception is the model from Kumhof and Ranciere (2010) and the model from Kumhof et al. (2012) that are both discussed in the next section.
} 


\section{The role of income inequality in the subprime crisis}

\subsection{Marxian explanations for the subprime crisis and the role of inequality}

Heterodox political economists that bring forward 'Marxian' explanations ${ }^{30}$ for the subprime crisis can be broadly divided into two groups. One group claims that low profit rates in the producing sector were the root cause for the crisis (e.g. Harman, 2009; Potts, 2011; Freeman, 2010; Choonara, 2009; Kliman, 2012; or, from a different perspective Brenner, 2009). A second group argues that rising inequality and the prevention of underconsumption is crucial to understand why the subprime crisis occurred (e.g. Bellamy Foster and Magdoff, 2009; Kotz, 2009; Harvey, 2010a; Onaran, 2010a, 2010b, 2011) ${ }^{31}$.

The argument of the 'falling rate of profit group' can be summarised as follows: At the end of the 1960s and during the 1970s the profit rates fell sharply in the US, Europe and Japan as the 'golden age' of high profits after World War II came to an end. Although profit rates recovered from the 1980s onwards somewhat, they stayed well below the rates of the 'golden age'. The reason being that the organic composition of capital changed (i.e. the constant to variable capital ratio increased) so that less surplus value per invested capital was achieved $^{32}$. These low profit rates led to less investment in the real sector which meant that "a growing [global] pool of growth of money capital [was] searching for outlets that seemed to promise higher levels of profitability ... All sorts of speculative, unproductive activities flourished [and the] financial system expanded as a consequence, since it played a key part in collecting together the funds for speculation" (Harman, 2009, p. 283). These developments thus fostered first the dot.com bubble and, after its collapse, the investment boom in the housing market followed because the securitisation of mortgages promised high returns for capitalists and thus was a convenient solution to escape the falling profit rate problematic. Many supporters of this theory also acknowledge that an increase in income inequality (i.e. the general decrease in real wages and social benefits) fostered the credit and the subprime mortgage demand from poor households to keep up their living standards. They claim however that the expansion of the financial sector, securitisation, speculation, and the

\footnotetext{
${ }^{30}$ Many heterodox economists claim that the subprime crisis was more a Minskian than a 'traditional' Marxian one (e.g. Moseley, 2008; O'Hara, 2009, Bellofiore, 2011) - the Minskian explanation for the subprime crisis will be discussed in Section 5.2).

${ }^{31}$ Obviously, the 'original' profit squeeze theory is not prominent to explain the low profit rates as real wages were constant or even falling in most countries prior to the crisis (as discussed in Section 2.4).

${ }^{32}$ Brenners' (2009) argument is different but also stresses that the low rate of profits is the culprit for the crisis. According to his analysis the low profit rates can be explained by the "intensification of international competition [which lead to] over-capacity in the global manufacturing sector ... tending to squeeze global prices and profits" (p.9).
} 
increase in inequality were only reactions to the decline in profit rates in the productive sector, and that therefore the general law of the tendency of profit ultimately is the root cause of the subprime crisis.

The proposition that low profit rates were the main underlying cause of the crisis is challenged by many heterodox economists though - also by some of those that explain the 1970s crisis with the fall in the profit rate due to the 'overaccumulation' of constant capital. Their critique rests upon three main points. Firstly, from 1982 onwards profit rates were recovering and although they were not reaching the peak level of the mid 1960s they were not particularly low - the rise in corporate profits was based mainly on rationalisation, rising levels of exploitation due to stagnant/decreasing real wages and increasing productivity, and decreasing corporate taxes (see e.g. Li et al., 2007; Moseley, 2007; Shaikh, 2011; Onaran, 2010a; Evans, 2010; Duménil and Lévy, 2012). Secondly, "the reference point for the capitalists in the post 1980 s was not the profit rates of the early 1960s in manufacturing, which might be higher than currently, but was the short-term and high return of financial assets" (Onaran, 2010a, p.4). Finally, the argument that an increase in constant capital accumulation led to the lower profit rates prior to the crisis is unconvincing on the ground that gross fixed investment was relatively low since the mid-1980s, while at the same time the labour force was expanded significantly on a global scale (Heartfield, 2008). ${ }^{33}$

Therefore, some heterodox authors (such as Bellamy Foster and Magdoff, 2009; Kotz, 2009; Panitch and Konings, 2009; Harvey, 2010a; Onaran, 2010a, 2010b; Mah-Hui and Hoe Ee, 2011; Russo, 2012) have put forward the argument that a 'Marxian' overproduction/underconsumptionist explanation for the crisis is more plausible and that the increase in income inequality needs to be given much more weight in the discussion ${ }^{34}$. The reason being, that the process of financialisation and the increasing demand for subprime mortgages can directly be attributed to the declining wage share and the increase in top

\footnotetext{
${ }^{33}$ Another challenge, which is discussed in detail in Chapter 4 (Section 4), comes from Lysandrou (2009, 2011a, 2011b) who argues the increase in the concentration of wealth in the hands of a tiny minority of the global population played a decisive role in the crisis according to this analysis.

${ }^{34}$ Please note that inequality is not seen as the sole cause by these authors but as a very fundamental one. Other crucial reason for the emergence of the crisis that are mentioned by these authors are: financial deregulation, financial innovation, an expansion of credit, speculative investment, the low federal fund interest rate between 2001-2004, the maturation of economies, the absence of groundbreaking innovations that stimulate the economy sufficiently (like the invention of the car), the absence of sufficiently large sinks for the surplus value (like huge urbanisation programmes, huge wars etc.), and increasing market concentration.
} 
management salaries since the 1980s (as discussed in Section 2.4) ${ }^{35}$ : the increasing profits needed to be reinvested which led to a potential 'capital surplus absorption problem', because the consumption demand from ordinary households was restricted due to their stagnant real wages. This potential realisation problem was overcome by an increase in debt levels (mainly by US and UK households) and exports (from countries like Germany, Japan, and China) on the one hand and by increasing investment of surplus values in the financial sector, which was freed more and more from constraining regulations ${ }^{36}$, on the other hand. The expansion of the financial sector meant that "[s]peculative finance became a kind of secondary engine for growth given the weakness in the primary engine, productive investment." (Bellamy Foster and Magdoff, 2009, p. 18). Consumption was thus stimulated by asset bubbles which lead to wealth effects, and at the same time more funds were channelled to poor households in the US - which, given their stagnant/declining wages, needed those funds to sustain their status and high consumption levels. This growth model relied on increasing issuance of credits (e.g. credit card debt, auto loans, and student loans) and subprime mortgages to (poor) households which was unsustainable in the long-run. Consequently, the "collapse of this [inequality driven] debt-led growth model was inevitable" (Onaran, 2010b).

\subsection{Post-Keynesian explanations for the subprime crisis and the role of inequality}

Post-Keynesians have brought forward many different explanations regarding the root causes of the subprime crisis, as can be seen from a special edition that was published in the most prestigious heterodox journal, the Cambridge Journal of Economics. Among these explanations have been technological and financial innovation (Perez, 2009), imbalances in exchange rate regimes and trade and capital flows (Wade, 2009), central bank policy failures (Morgan, 2009), increased banking concentration and banking leverage (Tregenna, 2009), and the set-up of the institutions of the knowledge economy with regard to intellectual property rights (Pagano and Rossi, 2009). However, arguably the two most widely stated reasons for the crisis, which also have been discussed in the special issue, are (i) failures in financial regulation (Crotty, 2009) in combination with Minskyan instability (Wray, 2009),

\footnotetext{
${ }^{35}$ Domhoff (2012), for example, reports that in the US CEO's pay and corporate profits went up by $300 \%$ and $100 \%$ respectively, while production workers pay only increased by $4 \%$ and the Federal minimum wage even decreased by $9 \%$ between 1990 and 2005 .

${ }^{36}$ The deregulation of the financial market is thus seen to be driven not only by ideology (neoliberalism) but also due to pragmatic reasons, i.e. to prevent stagnation.
} 
and (ii) the financialisation of the economy which led to an increase in income inequality (Palma, 2009).

That the Minskian instability hypothesis is so prominent in the post-Keynesian debate is a bit surprising at first sight because "Minsky viewed downturns as caused by investment cycles, not by housing-price collapses [and] he focused attention on non-financial and financial firms, not on households" (Dymski, 2010, p.240). However, proponents of the Minskian view claim that although the subprime crisis differs in important aspects, it can still be regarded as 'Minskian' because Minsky always stressed the important role of institutional changes, money managers, and securitisation in the modern financial system. Moreover, the housing bubble and the growth of the subprime market was a systemic problem that was the result of de-regulation, (over-)optimistic expectations and ratings, financial innovation (i.e. credit creation), the search for high returns, rising asset prices, high leverage, and Ponzi finance schemes. All of which took place in a prolonged period of relative stability, i.e. during the Great Moderation. Thus, the subprime crisis is seen as a good example of the inherent instability of financial markets by many post-Keynesians as it supports Minsky's view that 'stability is destabilising' (see e.g. Kregel, 2007; Whalen, 2007; Wray, 2008a, 2008b, 2009; Wray and Tymoigne, 2008; Vercelli, 2009).

Most proponents that discuss the subprime crisis in the light of Minskyian instability only mention inequality in passing, if at all. Two notable exceptions are Dymski (2010) and Kaboub et al. (2010). The latter state that "a major contributing factor to the conditions leading to aggressive subprime lending behaviour is the build-up and persistence of economic inequality that has intensified since 1980" (p.9), and Dymski stresses that an important institutional feature of the subprime crisis was that banks, from the beginning of the 1990s, increasingly targeted low income minorities who had previously been excluded from financial markets. Both thus find that inequality was an important feature in the Minskian instability process. Nevertheless, the advocates of the financialisation theory claim that the Minskian "theory only provides a partial and incomplete account of the [subprime] crisis" (Palley, 2010) and that aggregate demand, and thus also inequality, need to be at the heart of the analysis.

According to the financialisation theory, "[s]lower growth, higher inflation and unemployment, and falling profits and stock prices created growing discontent with the economic status quo" at the end of the 1970s (Crotty, 2012, p.83). This led to 'right-wing' economic coalitions which radically deregulated financial markets, while at the same time 
institutional investors gained importance and the market for corporate control developed. The outcome of these developments was the enormous growth of the financial sector in OECD countries and the rise of shareholderism, which meant that firms had increasing pressure to achieve high profits to satisfy rentiers. Along with its unfavourable effects on physical investment (as discussed in Section 3.2.1) the functional and personal income distribution in OECD countries was also negatively affected by this financialisation of the economy: (i) via the rising importance of the financial sector, which had high profits and paid high management salaries, (ii) via the increase in top management salaries and rentiers' income, (iii) via its pressure on companies to reduce non-managerial wage costs, and (iv) via its negative impact on trade union bargaining power and employment (Stockhammer, 2008; Palmer, 2009; Evans, 2010; Crotty, 2012).

The overall outcome of financialisation and the accompanying increase in intra-country inequality (as discussed in Section 2.4) thus should have been a lack of aggregate demand. This was, however, circumvented by a decrease in personal saving rates and an increase of wealth and debt financed consumption in some countries, i.e. Greece, Ireland, Portugal, Spain, UK, and the US, and by an increasing reliance on exports in the 'mercantilist' countries, i.e. Austria, Belgium, China, Germany, Japan, Netherlands (see Figure ). This post1980 global growth regime was only possible because of the increase in consumption expenditure and private housing investment in the $\mathrm{US}^{37}$. One reason why the US private expenditure could increase, despite stagnant wages of non-supervisory US workers and increasing income inequality ${ }^{38}$, was that the number of working hours per family was going up (mainly due to increased female participation). Another reason was cheap imports (mainly from China). The most important reason was, however, that the bottom $90 \%$ of US households stopped saving ${ }^{39}$ and at the same time massively increased their debt-to-income ratios (Palley, 2007, 2010ba, 2010b; Stockhammer, 2008, 2012a; Palmer, 2009; Horn et al., 2009; van Treeck, 2009b, 2012; Setterfield, 2010; Hein, 2011; van Treeck 2013; Hein and Truger, 2012).

\footnotetext{
37 Between 1980 and 2007 "private consumption as a share of GDP increased massively by almost 10 percentage points" (van Treeck, 2012, p.5).

38 "Real pre-tax income growth (excluding capital gains) has been considerably lower in 1977-2007 as compared to 1947-1977 for all families except for those at the very top" ... While the pre-1977 period thus can be termed the 'Great Divergence', the "first period is also referred to as the 'Great Convergence' ... as lower and middle incomes have grown faster than top incomes." (van Treeck, 2012, p.6).

${ }^{39}$ The personal savings rate in the US decreased from $10 \%$ in 1980 to $0.6 \%$ in 2007 (Palley, 2010a).
} 
Figure 1: Rising inequality as a cause of the crisis from a post-Keynesian perspective

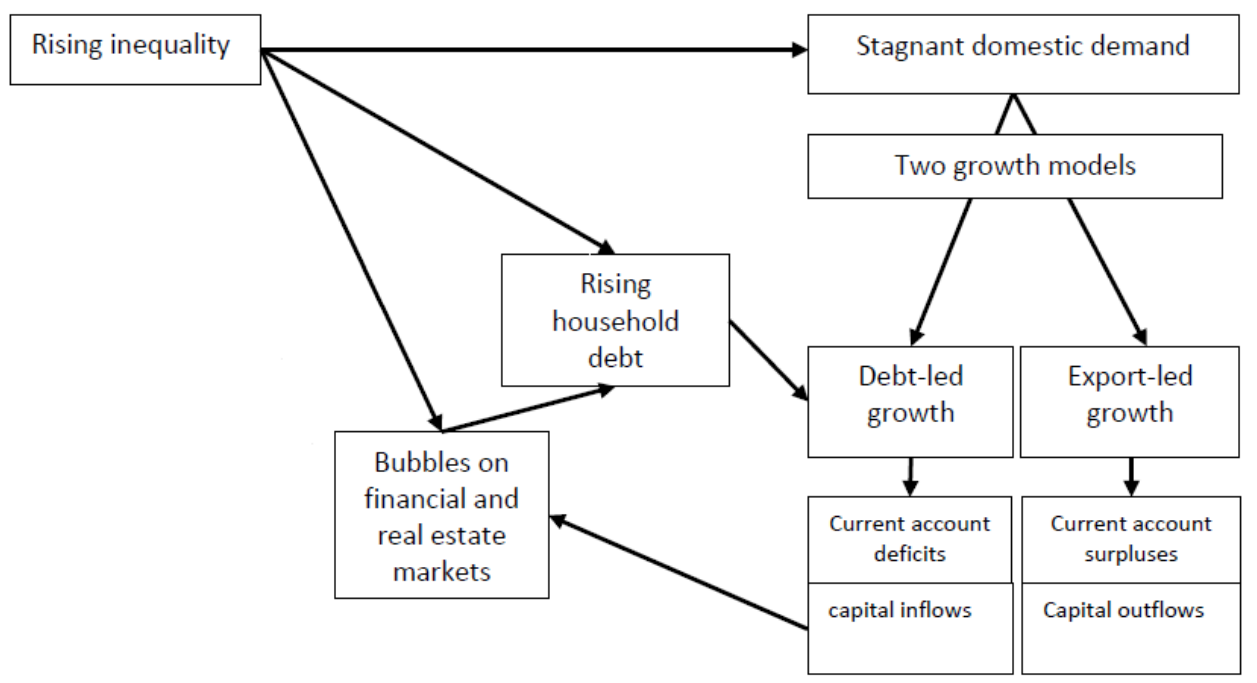

Source: Stockhammer (2012a); for simplicity reasons the impact of regulation is not shown in this version

The increased demand for credit was thus not the result of higher income mobility (which prior to the crisis was often argued by mainstream economists) but was instead the consequence of a rise in permanent income inequality in general and the rapid increase in the income of the top $1 \%$ in specific ${ }^{40}$. According to this post-Keynesian point of view, the dramatic increase of income of top earners in the US is very important for the story because, apparently, many US households lived for so long beyond their means in an effort to keep their social status relative to those wealthier members of the society. Top income driven inequality thus gave rise to an 'expenditure cascade' in which middle-income and poor households were only able to keep up with the rapidly increasing consumption of the top income earners by curtailing their savings and increasing their borrowing ${ }^{41}$ (Barba and Pivetti, 2009; Frank et al., 2010; Hein, 2011, 2012; van Treeck, 2013; van Treeck 2013). "[A]fter 1987 the amount of income considered necessary to get along again increased strongly, by more than 40 per cent until 2007”, whereas the increase in median income was much lower (15\%) during the same period (van Treeck and Sturn, 2012, p.17). As a consequence, the debt to income ratios of the bottom $95 \%$ of the US population in terms of income distribution increased from around $70 \%$ in the mid-1980s to around $140 \%$ in 2007 ,

\footnotetext{
40 "[D]uring the seven-year period of economic expansion of the Clinton administration the top $1 \%$ of income earners captured $45 \%$ of the total growth in (pre-tax) income, while during Bush's four-year period of expansion no less than $73 \%$ of total income growth accrued to the top 1\%." (Palmer, 2009, p.842).

${ }^{41}$ This relative income hypothesis, which states that to 'keep up with the Joneses' a fall in the personal saving rate and/or increase in borrowing is necessary, was originally developed by Duesenberry (1949).
} 
while the debt to income ratios of the richest $5 \%$ of the US population stayed relatively constant at around $70 \%$.

According to this view, inequality and debt-financed consumption are central to explaining the pre-crisis growth regimes and the collapse of the subprime market, next to important facilitating factors like de-regulation, financial innovation and the quest for high returns. The resulting tremendous increase in personal debt-levels was unsustainable in the long-run and led to a 'quasi' Minskyan instability in the household sector. Households engaged in Ponzi finance to finance consumption and relied on increasing house prices to be able to pay back their increasing debt. When the Fed increased the interest rates and the housing bubble bust these over-indebted subprime borrowers naturally could no longer repay their debt. This led to mass foreclosures, the breakdown of the market for collateralised debt obligations (CDOs), and a decrease in aggregate demand which also had negative consequences on the 'mercantilist' countries (Palley, 2010b; Setterfield, 2010).

\subsection{Mainstream explanations for the subprime crisis and the role of inequality}

The majority of mainstream economists think that either "there is no convincing link that would enable us to associate high levels of income inequality with the financial crisis" (Roháč, 2011, p.1) or that inequality might have played a facilitating role but that other factors were much more important. The most often discussed root causes of the crisis are therefore the lack of regulation (see e.g. Davies, 2010), greed on the part of the banks (see e.g. Brummer, 2009), the widespread undervaluation of risk (see e.g. IMF, 2008; Trichet, 2008), and global imbalances together with a misguided monetary policy based on too low interest rates (see e.g. Obstfeld and Rogoff, 2009).

Nevertheless, more and more prominent economists acknowledge that income inequality also was a root cause for the crisis. Rajan (2010) was one of the first that prominently theorised the link between inequality and the subprime crisis. According to his view skillbiased technological change increased permanent inequality in the US, and the "political response to [this] rising inequality ... was to expand lending to households, especially lowincome ones [with] the broader aims of expanding credit and consumption" (9). This expansion of credit led to a consumption boom (which helped to circumvent underconsumption problems in other countries and was financed by increasing capital inflows) and the over-indebtedness of US households which was not sustainable in the long-run. In 
accordance with heterodox economists Rajan thus also acknowledges the important role of credit to circumvent a possible demand shortage.

In contrast to post-Keynesian and Marxist economists, he is however not claiming that the economic system as such is prone to crisis. His main emphasis lies on government failure (in his view government incentives for financial markets and poor households ultimately enabled the increased borrowing of low income households) and educational failures (which lead to increasing inequality). This main conclusion with regard to policy recommendations is that education needs to be strengthened to decrease inequality, banking regulation should be strengthened to prevent speculation, and multilateral organisations should act to reduce the existing global imbalances, while domestic governments should not intervene otherwise.

In line with Rajan, other mainstream economists like Roubini (in a 2011 opinion piece), Krugman (2010), Reich (2010), Stiglitz (2009, 2012), Milanovic (2012), Kumhof and Ranciere (2010), and Kumhof et al. (2012) also reject the orthodox notion that there is no link between inequality and demand problems. In line with Rajan, Milanovic (2012, p.195) emphasises that "[p]oliticians were eager to 'solve' the irritable problem of middle-income stagnation" and thereby facilitated the access to housing for the middle class and poor with the aim of maintaining consumption. For Roubini (2011), on the contrary, the main problem is that "free markets don't generate enough final demand" so that increases in private debt are a consequence of a general failure of market forces.

Stiglitz $(2009,2012)$ agrees that the crisis has shown that the economic system is not always endogenously stable. He also argues that aggregate demand in the US and in the world in general would have been insufficient without the lax monetary policy after 2001 and the stock market bubble and then the housing bubble that "fuelled a consumption boom that allowed Americans to live beyond their means" (ibid, 2012, p.54) to keep up with the living standards of the richer parts of the population. For him the main reason for this problem is asymmetric information which led to market distortions, and coordination and macroeconomic failures. The resulting increasing power and rent seeking behaviour of the top $1 \%$, which successfully lobbied for less state intervention and less redistribution, and the decreasing power of the working class (due to de-regulation, globalisation and weaker labour unions) coupled with the sectoral shift away from manufacturing and the existing skill-biased technological change meant that polarization of incomes increased sharply prior to the crisis. However, this behaviour was unsustainable in the long run as households became overleveraged and because the housing bubble could not last forever. Krugman (2010) agrees 
that the influence of rich people on domestic policies has been a major problem, but in contrast to Stiglitz he is claiming that not underconsumption but overconsumption by poor and middle-income US households was a major problem prior to the crisis.

Like the heterodox economists, all of these mainstream authors acknowledge that next to the high inequality levels in the US the high levels of global inequality were also important. Vandemoortele (2009) especially stresses this link. According to his view "within- and between-country inequality are mutually reinforcing" (iv), while intra-country inequality led to an aggregate demand problem global inequality contributed to BoP imbalances, unequal capital flows and the accumulation of reserves, which all have played an important part in the run-up to the crisis. This point is conceptualized by Kumhof et al. (2012) who are using an open economy DSGE model which is based on a closed economy DSGE model developed by Kumhof and Ranciere (2010). Both models have two groups of households: investors (the top $5 \%$ of the population) and workers (the bottom 95\% of households). In the closed economy model crisis results from an external 'bargaining power shock' that results in increasing inequality. The increase in inequality leads to higher credit demand from workers who seek to smooth consumption, while the top 5\% recycle their gains to poorer households in the forms of loans. Over time workers get over-indebted and "large-scale household debt defaults [leading to] an abrupt output contraction" (p.1).

The 2012 extension of this model argues the result of increasing inequality on a global scale is that workers in countries that have highly developed financial markets (US, UK) borrow not only domestically but also from (emerging) economies which have a less developed financial system (China). The latter group of countries use an export oriented strategy to grow despite weak domestic consumption demand, while the rich part of their population recycles its increasing gains to developed economies with sophisticated financial markets. Countries with developed financial markets and current account deficits on the other hand overcome the under-consumption problem because of the ability and willingness of workers to increase their lending ${ }^{42}$. The authors conclude that the resulting increasing BoP imbalances and over-indebtedness of workers in rich countries contributed to the subprime crisis which affected both groups of countries negatively in the post-crisis period.

\footnotetext{
42 This theory does however not explain why in countries like Germany and Japan (which both have sophisticated financial markets) household debt levels were not increasing significantly - instead both countries relied on export-led growth.
} 


\section{Conclusions}

The previous discussion clearly shows that the issue of distribution is inherent in all Marxian crisis theories as they are all based on the notion of class struggle between capitalists and workers. The only Marxian theory which sees rising inequality as the root cause for crises is however the overproduction/underconsumption theory. For many post-Keynesians possible aggregate demand problems due to changes in the functional income distribution between workers, capitalists and rentiers are also at the heart of the analysis; but, fundamental uncertainty and Minskian instability (which are both normally not related to inequality by post-Keynesians) are at least as prominent in post-Keynesian crisis discussions. In contrast to Marxist and post-Keynesian economists, the vast majority of mainstream economists believe that the capitalist system is endogenously stable and that crises arise from exogenous shocks. Furthermore, prior to the crisis mainstream theories and models did not regard inequality as destabilizing factor.

In spite of these differences, economists from all three strands provide a similar explanation (most comprehensively articulated by post-Keynesians) why income inequality was a root cause of the subprime crisis: a possible global aggregate consumption demand problem was circumvented by a massive increase in household borrowing in some countries, mainly in the US and the UK, and a mercantilist export-led growth strategy in other countries, for example in China and Germany. The increase in borrowing by private households in debt-led countries was made possible by a stock market bubble and more importantly by a housing bubble and financial liberalisation. The driving force for this increasing demand for loans was that in an era of stagnant real wages low- and middleincome households wanted to keep their status in relation to richer peers which had increasing incomes ('keeping up with the Joneses' effect). Over time global BoP imbalances increased and many of the bottom $90 \%$ households became over-indebted. The collapse of this system occurred in summer 2007 when the delinquency rates of US households - due to rising interest rates and falling house prices - on subprime and jumbo mortgages became too high. The subsequent breakdown of the CDO market made the bailouts of banks across the world necessary and culminated in a global credit crunch and recession. The impact of the crisis on the real economy was felt strongest in debt-led countries, as consumption via borrowing was no longer possible, but was felt also in mercantilist countries due to the decrease in their exports. 
Rising intra-country income inequality and the high level of global income inequality (see Goda (2013) for an overview about global changes in inequality levels) thus are seen as important contributing factors for the crisis by heterodox and some mainstream economists. This finding clearly indicates that high levels of economic inequality not only can have adverse social impacts but also can foster economic instability. This must not always be the case though. According to the profit squeeze theory a decrease in inequality might also lead to a crisis in a capitalist system if profits are lowered too much (see e.g. Glynn et al., 1991). Recent empirical research by Bordo and Meissner (2012) and Atkinson and Morelli (2011) furthermore suggest that institutional and country-specific circumstances need to be taken into account to establish if high levels of income inequality have adverse effects.

This might explain why the majority of economists nonetheless still give primacy to other factors than inequality to explain the root causes of the subprime crisis, namely the deregulation of the financial sector, the lax monetary policy after 2001, wrong government incentives, and the greedy behaviour of the financial sector. Another important reason why inequality is not at the forefront of debate is that changes in income inequality explain why the household demand for (subprime) mortgages and other loans was rising, but they cannot fully explain why these credits have been re-securitised into debt securities whose default triggered the financial crisis (i.e. into CDOs). Changes in wealth concentration (i.e. the increasing investment demand from very rich individuals) thus also need to be taken into account to close this gap in explanatory power and to give economic inequality a more prominent role in the debate (see Goda and Lysandrou, 2011).

\section{References}

Akerlof, George A. (2002): Behavioral macroeconomics and macroeconomic behaviour. American Economic Review, 92(3), pp. 411-433.

Allen, Frank, and Gale, Douglas (2007): Understanding Financial Crises. Oxford University Press: New York.

Arestis, Philip (1996): Post-Keynesian economics: towards coherence. Cambridge Journal of Economics 20(1): 111-135.

Arestis, Philip, and Glickman, Murray (2002): Financial crisis in Southeast-Asia: dispelling illusion the Minskyan way. Cambridge Journal of Economics, Vol. 26(2): 237-260. 
PKSG The role of income inequality in crisis theories and in the subprime crisis

Atkinson, Anthony B. (1997): Bringing income distribution in from the cold. The Economic Journal, Vol. 107(441): 297-321.

Atkinson, Anthony, and Morelli, Salvatore (2010): Inequality and Banking Crises: A First Look. Paper prepared for the European Labour Forum in Turin organised by the ILO.

Baran, Paul, and Sweezy, Paul M. (1966): Monopoly Capital. Monthly Review Press: New York.

Barba, Aldo, and Pivetti, Massimo (2009), Rising household debt: Its causes and macroeconomic impli-cations - a long-period analysis. Cambridge Journal of Economics, Vol. 33(1), 113-137.

Bell, Peter and Cleaver, Harry (2002): Marx's theory of crisis as a theory of class struggle. The Commoner, no. 5: 1-61 (first published in Research in Political Economy Vol. 5 (1982)).

Bellamy Foster, John, and Magdoff, Fred (2009): The great financial crisis: causes and consequences. Monthly Review Press: New York.

Bellamy Foster, John, and McChesney, Robert W. (2010): Listen Keynesians, It's the system! Response to Palley. Monthly Review, Vol. 61(11).

Bellofiore, Riccardo (2011): From Marx to Minsky: The Universal Equivalent, Finance to Production and the Deepening of the Real Subsumption of Labour under Capital in Money Manager Capitalism. In Ganssmann, H. eds. "New approaches to monetary theory. Interdisciplinary perspectives". Routledge: Abingdon \& New York, pp. 191211.

Bhaduri, Amit (2011): A contribution to the theory of financial fragility and crisis. Cambridge Journal of Economics 35(6): 995-1014.

Bhaduri, Amit, and Marglin, Stephen (1990): Unemployment and the real wage: the economic basis for contesting political ideologies. Cambridge Journal of Economics, Vol. 14(4): 375-93.

Bhaduri, Amit, Laski, Kazimierz, and Riese, Martin (2006): A model of interaction between the virtual and the real economy, Metroeconomica, Vol. 57(3), 412-27.

Bordo, M.D. and Meissner, C.M. (2012). 'Does inequality lead to a financial crisis?'. NBER Working Paper, No. 17896.

Boyer, Robert (2000): Is a finance-led growth regime a viable alternative to Fordism? A preliminary analysis', Economy and Society, 29(1): 111-145.

Brenner, Robert (2009): What is good for Goldman Sachs is good for America; the origins of the current crisis. Retrieved at 26.02.2012 from http://www.sscnet.ucla.edu/issr/cstch/ papers/BrennerCrisisTodayOctober2009.pdf.

Choonara, Joseph (2009): Marxist accounts of the current crisis. International Socialism, issue 123, Retrieved at 26.02.2012 from http://www.isj.org.uk/?id=557. 
Clarke, Simon (1994): Marx’s Theory of Crisis. Macmillan Press: Basingstoke.

Crotty, James (1985): The Centrality of Money, Credit and Financial Intermediation in Marx's Crisis Theory. In Resnick, S. and Wolff, R. eds., Rethinking Marxism: Essays in Honor of Harry Magdoff and Paul Sweezy. New York: Autonomedia, pp. 45-82.

Crotty, James R. (1980): Post-Keynesian Economic Theory: An Overview and Evaluation. American Economic Review 70(2): 20-25.

Crotty, James R. (2009): Structural causes of the global financial crisis: a critical assessment of the 'new financial architecture'. Cambridge Journal of Economics, Vol. 33(4): 563580 .

Crotty, James R. (2012): The great austerity war: what caused the US deficit crisis and who should pay to fix it? Cambridge Journal of Economics, Vol. 36(): 79-104

Davidson, Paul (1984): Reviving Keynes's revolution. Journal of Post Keynesian Economics, Vol. 6(4): 561-575.

Davidson, Paul (2003-2004): Setting the record straight on A history of Post Keynesian economics. Journal of Post Keynesian Economics Vol. 26(2): 245-272.

Diamond, Douglas W., and Dybvig, Philip H. (1983): Bank Runs, Deposit Insurance, and Liquidity. Journal of Political Economy, Vol. 91(3): 401-419.

Dobb, Maurice (1939): Political economy and capitalism. International Publisher: New York.

Domhoff, G. William (2012) 'Wealth Income, and Power' (update March 2012). Retrieved at 12.05.2012 from http://sociology.ucsc.edu/whorulesamerica/power/wealth.html.

Dornbusch, Rudi (2001): A primer on emerging market crisis. NBER Working Paper 8326.

Duesenberry, James S. (1949): Income, Saving and the Theory of Consumer Behavior, Harvard University Press.

Dullien, Sebastian (2009): The New Consensus from a Traditional Keynesian and PostKeynesian Perspective A worthwhile foundation for research or just a waste of time? IMK Working Paper 12/2009.

Duménil, Gérard, and Lévy , Dominique (2012): The Crisis of the Early 21st Century: Marxian perspectives. In Bellofiore, R., Vertova, G.( eds.) "The Great Recession and the contradictions of contemporary capitalism". Edward Elgar: Aldershot.

Dutt, Amitava K. (2006): Maturity, stagnation and consumer debt: a Steindlian approach. Metroeconomica, Vol. 57(3): 339-64.

Dutt, Amitava K. (2011): Power, uncertainty, and income distribution: towards a theory of crisis and recovery. FMM Conference 'From crisis to growth? The challenge of imbalances, debt, and limited resources', October 28-29, Berlin.

Engels, Friedrich (1975): Anti-Dühring: Her Eugen Dühring's Revolution in science. Lawrence \& Wishart: London. 
PKSG The role of income inequality in crisis theories and in the subprime crisis

Epstein, Gerald A. (2005): Introduction and distributional implications. In Epstein, G.A. (eds.): Financialization and the World Economy, Cheltenham: Edward Elgar.

Evans, Trevor (2004): Marxian and post-Keynesian theories of finance and the business cycle. Capital \& Class, vol. 28(2): 47-100.

Evans, Trevor (2010): Five explanations for the international financial crisis. IPE Working Paper No. 08/2010.

Fama, Eugene F. (1970). Efficient Capital Markets: a review and empirical work. Journal of Finance, Vol. 25(2): 383-417.

Fama, Eugene F. (1991). Efficient Capital Markets: II. The Journal of Finance. 46(5): 15751617.

Fernandez, Luisa, Kaboub, Fadhel, and Todorova, Zdravka (2008): On democratizing financial turmoil: a Minskian analysis of the subprime crisis. Levy Economics Institute Working Paper No. 548.

Ferrari-Filho, Fernando, and Camargo Conceicao, Octavio A. (2005): The concept of uncertainty in Post Keynesian theory and in institutional economics. Journal of Economic Issues, Vol. 39(3): 579-94.

Fischer, Andrew M. (2011): Beware the fallacy of productivity reductionism. European Journal of Development Research, Vol. 23(4): 521-526.

Franck, R.H., Levine, A.S., and Dijk, O. (2010): Expenditure Cascades.

Freeman, Alan (2010): Marxism without Marx: a note towards a critique. Capital and Class 34(1): 84-97.

Friedman, Milton (1953): Essays in Positive Economics. Chicago, London: University of Chicago Press.

Goda, T. (2013). Changes in income inequality from a global perspective: an overview. PKSG Working Paper No. 1303.

Goda, T., and Lysandrou, P. (2011). The contribution of wealth concentration to the subprime crisis: a quantitative estimation. CIBS Working Paper No. 22.

Glynn, A. and Sutcliffe, B. (1972): British capitalism, workers and the profit squeeze. Penguin: Harmondsworth.

Grabel, Irene (1995): Speculation-led economic development: a post-Keynesian interpretation of financial liberalization programmes in the Third World. International Review of Applied Economics, Vol. 9(2): 127-49.

Hamouda, Omar F., and Harcourt, Geoff C. (1988): Post Keynesianism: from criticism to coherence? Bulletin of Economic Research 40(1): 1-32.

Harman, Chris (2009): Zombie Capitalism: Global crisis and the relevance of Marx. Bookmarks Publications. 
PKSG The role of income inequality in crisis theories and in the subprime crisis

Harvey, David (2010): The enigma of capital: and the crises of capitalism. Profile Books: London.

Harvey, John T. (2010): Modelling financial crisis: a schematic approach. Journal of Post Keynesian Economics, Vol. 33(1): 61-82.

Heartfield, James (2008): Living Marx. Retrieved at 26.02.2012 from http://platypus1917.org/2008/12/01/living-marxism/

Hein, Eckhard (2011): Distribution, 'Financialisation' and the Financial and Economic Crisis Implications for Post-crisis Economic Policies. MPRA Working Paper No. 31180.

Hein, Eckhard (2012): Finance-dominated capitalism, re-distribution, household debt and financial fragility in a Kaleckian distribution and growth model. PSL Quarterly Review, Vol. 65(260): 11-51.

Hein, Eckhard, and Stockhammer, Engelbert (2011): A post-Keynesian macroeconomic model of inflation, distribution and employment. In Hein. E. and Stockhammer, E. (eds.): A modern guide to Keynesian macroeconomic and economic policies. Cheltenham: Edward Elgar Publishing.

Hein, Eckhard, and Truger, Achim (forthcoming): Finance-dominated capitalism in crisis the case for a global Keynesian New Deal, Journal of Post Keynesian Economics.

Hein, Eckhard, and van Treeck, Till (2008): 'Financialisation' in Post-Keynesian models of distribution and growth - a systematic review, IMK Working Paper No.10/2008.

Hilferdinger, Rudolf (1910): Das Finanzkapital. Eine Studie über die jüngste Entwicklung des Kapitalismus. Wiener Volksbuchhandlung: Vienna.

Horn, Gustav, Dröge, Katharina, Sturn, Simon, van Treeck, Till, and Zwiener, Rudolf (2009): From the financial crisis to the world economic crisis: the role of inequality. IMK Report No. 41.

Jespersen, Jesper (2009): Macroeconomic Methodology A Post-Keynesian Perspective. Cheltenham: Edward Elgar Publishing.

Jessop, Bob (2011): Crises of Crisis-Management: Lessons from the Global Financial Crisis. Presentation at the CIBS Norman Stang Research Seminar in Economics, 4 April, London.

Kahneman, Daniel, and Tversky, Amos (1979): Prospect theory: An Analysis of Decision Under Risk. Econometrica, Vol. 47(2): 263-91.

Kautsky, Karl (1901-1902): Krisentheorien. Die Neue Zeit 20(2): 37-47, 76-81, 110-118, $133-43$.

Keer, Prue (2005): Review Article: A history of post-Keynesian economics. Cambridge Journal of Economics 29(3): 457-496.

Kenway, Peter (1980): Marx, Keynes and the possibility of crisis. Cambridge Journal of Economics, Vol. 4(1): 23-36. 
PKSG The role of income inequality in crisis theories and in the subprime crisis

Keynes, John M. (1936): The General Theory of Employment, Interest and Money. London: Macmillan (1960 reprint).

Keynes, John M. (1937): The general theory of employment. Quarterly Journal of Economics, Vol. 51(2): 209-223.

Kindleberger, Charles P., and Aliber, Robert Z. (2005): Manias, Panics and Crashes: A history of financial crises. Palgrave Macmillan: New York. 5th edition.

King, John E. (2005): Unwarping the record: a reply to Paul Davidson. Journal of Post Keynesian Economics 27(3): 377-384.

Kliman, Andrew (2012): The Failure of Capitalist Production: Underlying Causes of the Great Recession. Pluto Press: London.

Kotz, David M. (2009): The Financial and Economic Crisis of 2008: A Systemic Crisis of Neoliberal Capitalism. Review of Radical Political Economics, vol. 41(3): 305-317.

Kregel, Jan (2007): The Natural Instability of Financial Markets. Levy Economics Institute Working Paper No. 523.

Krugman, Paul (1999): Balance sheets, the transfer problem, and financial crises. International Tax and Public Finance, Vol. 6(4): 459-72.

Kumhof, Michael, and Ranciere, Romain (2010): Inequality, leverage and crises. IMF Working Paper No. 268.

Kumhof, Michael, Lebarz, Claire, Ranciere, Romain, Richter, Alexander W., and Throckmorton, Nathanial A. (2012): Income Inequality and Current Account Imbalances. IMF Working Paper No. 12/08.

Lavoie, Marc (2005): Changing definitions: a comment on Davidson's critique of King's history of Post Keynesianism. Journal of Post Keynesian Economics 27(3): 371-376.

Lavoie, Marc (2006): Introduction to Post-Keynesian Economics. Houndmills: Palgrave Macmillan.

Li, Minqi, Xiao, Feng, and Zhu, Andong (2007): Long Waves, institutional changes, and historical trends: a study of the long-term movement of the profit rate in the capitalist world-economy. Journal of World-Systems Research, vol. 13(1): 33-54.

Luxemburg, Rosa (1913): The accumulation of capital. Butler \& Tanner: Frome \& London.

Mah-Hui, Michael L., and Hoe Eee, Khor (2011): From Marx to Morgan Stanley: Inequality and Financial Crisis. Development and Change, Vol. 42(1): 209-227.

Malthus, Thomas R. (1820): Principles of political economy considered with a view to their practical application. London: John Murray.

Marx, Karl (1993): Grundrisse: Foundations of the Critique of Political Economy (Rough Draft). Penguin Books: London.

Mattick, Paul (1971): Marx and Keynes: the limits of the mixed economy. Merlin Press: London. 
PKSG The role of income inequality in crisis theories and in the subprime crisis

Minsky, Hyman P. (1986): Stabilizing an Unstable Economy. New Haven and London, Yale University Press.

Minsky, Hyman P. (1992): The Financial Instability Hypothesis. Working Paper No. 74. The Jerome Levy Economics Institute of Bard College.

Morgan, Jamie (2009): The limits of central bank policy: economic crisis and the challenge of effective solutions. Cambridge Journal of Economics, Vol. 33(4): 581-608.

Moseley, Fred (2008): Some Notes on the crunch and the crisis. International Socialism, issue 119. Retrieved at 26.02.2012 from http://www.isj.org.uk/?id=463.

Mosely, Fred (2007): Is the U.S. economy headed for a hard landing? Retrieved at 26.02.2012 from http://www.permanentrevolution.net/entry/1812.

Muñoz (2011): Orthodox versus Heterodox (Minskyan) Perspectives of Financial Crises: Explosion in the 1990s versus Implosion in the 2000s. Levy Economics Institute Working Paper No. 659.

Nesvetailova, Anastasia (2007): Fragile Finance: Debt, Speculation and Crisis in the Age of Global Credit. Basingstoke: Palgrave Macmillan

Krugman, Paul (2010): Inequality and crises: coincidence or causation? Presentation at the Luxembourg Income Study research conference: Inequality and the Status of the Middle Class: Lessons from the Luxembourg Income Study, Walferdange, June 28-30.

O'Hara, Phillip A. (2009): The global securitized subprime market crisis. Review of Political Economics, vol. 41(3): 318-334.

Onaran, Özlem (2006): Speculation-led growth and fragility in Turkey: Does EU make a difference or "can it happen again"? In Hein, Eckhard, and Heise, Arne, and Truger, Achim (eds.): European Economic Policies: Alternatives to Orthodox Analysis and Policy Concepts. Marburg: Metropolis.

Onaran, Özlem (2010a): Global crisis and the policy reaction in Western and Eastern European Union: can policy save capitalism from itself? Retrieved at 26.02.2012 from http://internationalviewpoint.org/spip.php?article1797.

Onaran, Özlem (2010b): The Crisis of Capitalism in Europe, West and East. Monthly Review 62(5).

Onaran, Özlem (2011): From wage suppression to sovereign debt crisis in Western Europe: who pays for the costs of the crisis? International Journal of Public Policy 2011, Vol. 7(1/2/3): $51-69$.

Onaran, Özlem, and Galanis, Giorgos (2012): Is aggregate demand wage-led or proft-led? National and global effects. ILO Conditions of Work and Employment Series No. 31.

Pagano, Ugo, and Rossi, Maria A. (2009): The crash of the knowledge economy. Cambridge Journal of Economics, Vol. 33(4): 665-683. 
PKSG The role of income inequality in crisis theories and in the subprime crisis

Palley, Thomas I. (2002): Economic contradictions coming home to roost? Does the U.S. economy face long-term aggregate demand generation problem? Journal of Post Keynesian Economics, Vol. 25(1): 9-32.

Palley, Thomas I. (2007): Financialization: What it is and Why it Matters. PERI Working Paper No. 153.

Palley, Thomas I. (2010a): America's exhausted paradigm: macroeconomic causes of the financial crisis and great recession. New School Economic Review, Vol. 4(1): 15-43.

Palley, Thomas I. (2010b): The limits of Minsky's financial instability hypothesis as an explanation of the crisis. Monthly Review, Vol. 61(11).

Palma, José G. (2009): The revenge of the market on the rentiers. Why neo-liberal reports of the end of history turned out to be premature. Cambridge Journal of Economics, Vol. 33(4): 829-869.

Panitch, Leo, and Konings, Martijn (2009): Myths of neoliberal deregulation. New Left Review 57: 67-83.

Perez, Carlota (2009): The double bubble at the turn of the century: technological roots and structural implications. Cambridge Journal of Economics, Vol. 33(4):779-805.

Potts, Nick (2011): Marx and the crisis. Capital \& Class, vol. 35(3): 455-473.

Rajan, Raghuram G. (2010): Fault lines: how hidden fractures still threaten the world economy. Princeton: Princeton University Press.

Reich, Robert B. (2010): Aftershock: The next economy and america's future. New York: Random House.

Reinhart, Carmen, and Rogoff, Kenneth S. (2010): Growth in a Time of Debt. NBER Working Paper 15639.

Roháč, Dalibor (2011): Does inequality matter? Adam Smith Institute Briefing Paper.

Roubini, Nouriel (2011): The instability of inequality. Retrieved at 10 January 2012 from http://www.project-syndicate.org/commentary/the-instability-of-inequality.

Rosser, J. Barkley (2003): A Nobel Prize for Asymmetric Information: The economic contributions of George Akerlof, Michael Spence and Joseph Stiglitz. Review of Political Economy, Vol. 15(1): 3-21.

Rowthorn, Bob (1980): Capitalism, Conflict \& Inflation. Lawrence and Wishart: London.

Russo, Alberto (2012): From the neoliberal crisis to a new path of development. MPRA Working Paper 38004.

Setterfield, Mark (2010): Real Wages, Aggregate Demand, and the Macroeconomic Travails of the US Economy: Diagnosis and Prognosis. Trinity College Department of Economics Working Paper 10-05.

Setterfield, Mark (2011): Anticipations of the crisis: on the similarities between postKeynesian Economics and Regulation Theory. Revue de la régulation, Vol. 10(2). 
Shaikh, Anwar (1978): An introduction to the history of crisis theories. In "US Capitalism in Crisis". Union for Radical Political Economics: New York.

Shaikh, Anwar (2011): The first great depression of the 21st century. Socialist Register, vol. 47: 44-63.

Shiller, Robert J. (2000): Irrational exuberance. Princeton University Press: Princeton.

Shleifer, Andrei (2000): Inefficient Markets: An Introduction to Behavioral Finance Oxford University Press: New York.

Sismondi, Jean C.L. (1819): Nouveaux principes d'économie politique, ou de la Richesse dans ses rapports avec la population. Paris

Spence, Andrew M. (1973): Job Market Signaling. Quarterly Journal of Economics, 87(3): 355-374.

Stiglitz, Joseph E. (1992): Capital markets and economic fluctuations in capitalist economies. European Economic Review, Vol. 36(2-3), pp. 269-306.

Stiglitz, Joseph E. (2000): Capital market liberalization, economic growth, and instability. World Development, Vol. 28(6): 1075-1086.

Stiglitz, Joseph E. (2002): Information and the change in the paradigm in economics. American Economic Review, 92(3), pp. 460-501.

Stiglitz, Joseph E. (2009): The global crisis, social protection and jobs. International Labour Review 148(1-2): 1-13.

Stiglitz, Joseph E. (2012): The price of inequality. Penguin Books: London

Stockhammer, Engelbert (2004): Financialisation and the slowdown of accumulation. Cambridge Journal of Economics, Vol. 28(5): 719-741.

Stockhammer, Engelbert (2005-6): Shareholder value orientation and the investment-profit puzzle. Journal of Post Keynesian Economics, 28(2): 193-215.

Stockhammer, Engelbert (2008): Some stylized facts on the finance-dominated accumulation regime. Competition \& Change, Vol. 12(2): 184-202.

Stockhammer, Engelbert (2012): Rising Inequality as a Root Cause of the Present Crisis. PERI Working Paper No. 282.

Sweezy, Paul M. (1942): The theory of capitalist development: principles of Marxian political economy. Oxford University Press: New York.

Tornell, Aaron, Westermann, Frank, and Martínez, Lorenza (2004): The positive link between financial liberalization, growth, and crises. NBER Working Paper 10293.

Tregenna, Fiona (2009): The fat years: the structure and profitability of the US banking sector in the pre-crisis period. Cambridge Journal of Economics, Vol. 33(4): 609-632.

van Treeck, Till (2009a): A synthetic, stock-flow consistent macroeconomic model of ‘financialisation'. Cambridge Journal of Economics, Vol. 33(3):467-493. 
PKSG The role of income inequality in crisis theories and in the subprime crisis

van Treeck, Till (2009b): The macroeconomics of 'financialisation' and the deeper origins of the crisis. IMK Working Paper No. 9/2009.

van Treeck, Till (2013): Did inequality cause the U.S. financial crisis? Journal of Economic Surveys, early view online: DOI: 10.1111/joes.12028.

Van Treeck, Till, and Sturn, Simon (2012): Income inequality as a cause of the Great Recession? A survey of current debates. ILO Conditions of Work and Employment Series No. 39.

Vandemoortele, Milo (2009): Within-country inequality, global imbalances and financial instability. ODI Research Report. Retrieved at 08 October 2011 from http://www.odi.org.uk/publications/4165-inequality-global-imbalances-financialinstability

Vercelli, Alessandro (2009): A Perspective on Minsky Moments: The Core of the Financial Instability Hypothesis in Light of the Subprime Crisis. Levy Economics Institute Working Paper No. 579.

Wade, Robert (2009): From global imbalances to global reorganisations. Cambridge Journal of Economics, Vol. 33(4): 539-562.

Whalen, Charles (2007): The US credit crunch of 2007. Levy Economics Institute Policy Brief No. 92.

Wray, L. Randall (1990): Money and Credit in Capitalist Economies: The Endogenous Money Approach. Adlershot: Edward Elgar.

Wray, L. Randall (2008): Financial Markets Meltdown: What can we learn from Minsky? Levy Economics Institute Public Policy Brief No. 94a.

Wray, L. Randall (2009): The rise and fall of money manager capitalism: a Minskian approach. Cambridge Journal of Economics, Vol. 33(4): 807-828.

Wray, L. Randall, and Tymoigne, Éric (2008): Macroeconomics Meets Hyman P. Minsky: The Financial Theory of Investment. Levy Economics Institute Working Paper No. 543. 